\title{
Mechanical Properties of Basalt Fiber Reinforced Fly Ash-Based Geopolymer Composites
}

\author{
Kinga Korniejenko1, Gábor Mucsi², Nóra Papné Halyag², Roland Szabó², \\ Dariusz Mierzwiński ${ }^{1}$, and Petr Louda ${ }^{3}$ \\ ${ }^{1}$ Cracow University of Technology, Faculty of Materials Engineering and Physics, Institute of \\ Materials Engineering, Jana Pawła II 37, 31-864, Cracow, Poland \\ ${ }^{2}$ University of Miskolc, Institute of Raw Material Preparation and Environmental Processing, 3515 , \\ Miskolc, Egyetemváros, Hungary \\ ${ }^{3}$ Technical University of Liberec, Faculty of Mechanical Engineering, Department of Material \\ Science, Studentska 2, Liberec, 461 17, Czech Republic
}

\section{Abstract}

This article analyses the influence of a short basalt fibre admixture on the mechanical properties of geopolymers, especially compressive strength. This preliminary research is the first step towards the development of a composite for fire resistant applications in civil engineering. This study investigates the behaviour of a fly ash based geopolymer containing basalt fibres. Fly ash from the coal power plant 'Skawina' (located in: Skawina, Lesser Poland, Poland) was used as the raw material. The chemical composition of this fly ash is typical for class F. Three series of fly ash based geopolymers were cast. In the first, short basalt fibres were added as $1 \%$ by weight of fly ash, in the second short basalt fibres were added as $2 \%$ by weight of fly ash and the third functioned as a control series without any fibres. Each series of samples were tested on compressive strength after 28,14 and 7 days, and specimen density was determined. Additionally, microstructural analysis was carried out after 28 days. The results show that the addition of basalt fibres can improve the mechanical properties of geopolymer composites.

(c) Kinga Korniejenko et al. This article is distributed under the terms of the Keywords: geopolymer, basalt fibre, composites, fire resistance

\section{Introduction}

Geopolymer binder is a brittle material with a relatively low tensile strength and deformation capacity. To rectify these issues, reinforcement is required [1, 2]. In particular, the brittleness of these materials results in cracking under tensile and flexural loading $[1,2]$. The challenge is to replace the conventional steel bars traditionally applied in construction industry, through the proper short fibres [3]. The one possibility is mineral fibres. They have reasonable mechanical properties and are a cost-effective alternative. Moreover, the mechanical properties of mineral fibres tend to be greater than those offered by the use of natural fibres for reinforcement $[4,5]$. 
Among the mineral additives, the widest research was conducted on basalt fibres. There were implemented to geopolymer matrix as fabrics [6-8], long fibres [9], as well as short fibres and microfibers. The short basalt fibres were investigated in different types of matrix, including: metakaolin, slag and fly ash. The microscopic investigations by using a scanning electron microscope, showed very good coherence of these fibres to the different matrix, in contrast to glass and carbon fibres [10].

Research based on a geopolymer matrix made of metakaolin with three mineral additives: short basalt fibres, wollastonite and thermolite particles were performer [11]. Optimal mechanical properties - compressive strength - were obtained for a composite with $5 \%$ wollastonite, $5 \%$ thermolite and $2 \%$ basalt fibre [11]. The compressive strength increased for the selected composition to $33.5 \mathrm{MPa}$, compared to a value of $13 \mathrm{MPa}$ for the metakaolin matrix. Additionally, the selected composition was tested for strength after 3, 7, 28 and 90 days for resistance against aggressive environments, i.e. $15 \% \mathrm{Na}_{2} \mathrm{SO}_{4}$ solution and $15 \% \mathrm{NaCl}$ solution. The fibre composites retained higher mechanical properties than the geopolymer matrix itself [11]. Other studies based on a geopolymer matrix made of metakaolin with the addition of 1, 3, 5, 7 and $10 \%$ by weight of short basalt fibres were conducted, among others in terms of flexural strength. The fibres had about $0.64 \mathrm{~cm}(0.25 \mathrm{inch})$ long and $13 \mu \mathrm{m}$ in diameter [12]. The strength properties increased with the addition of fibre. For a plain matrix, the flexural strength was $1.7 \mathrm{MPa}$ and increased with the addition of basalt fibres - it was respectively: $1 \%$ 3.6 MPa, 3\% - 8.6 MPa, 5\% - 13.5 MPa, 7\% - 16.5 MPa and 10\% - 19.5 MPa [12]

The investigations were also carried out on a matrix based on fly ash class $F$ from Raichur Thermal Power Station, Karnataka, India (class F fly ash), with the addition of slag, basalt fibre, plasticizer (MYK Remicrete PC 5) and two types of aggregates (fine and coarse) [13]. The tests were carried out on composites with the addition of $0.5,1,1.5$, 2, 2.5 fibres by weight and plain samples for comparison. The compressive strength was tested after 7 and 28 days. As expected, the strength values for all composites after 28 days were higher, compared to the values obtained after 7 days, for matrix material they were $30.8 \mathrm{MPa}$ and 43.3 MPa, respectively. The composition with fibres had higher values than plain matrix. The best result was achieved for $2 \%$ fibre content - 40.1 MPa and 58.4 MPa [13]. Tensile tests were also tested. Strength values for the matrix material were: 2.2 MPa after 7 days and $2.4 \mathrm{MPa}$ after 28 days. Maximum values were also obtained for composites with a 2\% fibre addition: 3.2 MPa and 3.6 MPa [13].

Tests on the mechanical properties of composites with the addition of basalt fibres were also carried out on the basis of a matrix consisting of fly ash - class C, slag after processing of steel and sand [14]. The basalt fibres (diameter: 7-30 $\mu \mathrm{m}$ and lengths: 
$12 \mathrm{~mm}$ ), were added in following amount: $0.0,0.1,0.2,0.3,0.4$ and $0.5 \%$ by volume. Samples were tested after 3,7 and 28 days [14]. The compressive strength increased with time for all composites, after 3 days it was about $15 \mathrm{MPa}$, after 7 days - about 22 $\mathrm{MPa}$, and after 28 days - about $35 \mathrm{MPa}$. All composites achieved higher values than the matrix material. The highest values were obtained for $0.4 \%$ volume addition of basalt fibres, it was 40.3 MPa, compared to values around $35 \mathrm{MPa}$ for matrix [14]. For bending strength, the value after 3 days was about $3 \mathrm{MPa}$, after 7 days - about $4 \mathrm{MPa}$, and after 28 days - about 6.5 MPa. All composites achieved higher values than the plain matrix. The highest values were obtained for $0.3 \%$ by volume of fibres, it was $7.3 \mathrm{MPa}$ [14].

Compression, tensile and bending strength tests were carried out for samples with $0.5 \%$ and $1 \%$ basalt fibres. The geopolymer matrix was based on metakaolin. Additionally, the investigation were carried out on a matrix based on Portland cement for comparison [15]. The compressive strength decreased for both materials together with the addition of basalt fibres with a simultaneous increase in tensile and flexural strength [15]. The compressive strength for the geopolymer matrix were $39.5 \mathrm{MPa}$, and after addition of $0.5 \%$ and $1 \%$ basalt fibre $28.6 \mathrm{MPa}$ and $36.9 \mathrm{MPa}$, respectively. For comparison, the value for concrete based on Portland cement, without the addition of fibres, was: 23.1 MPa [15]. The tensile strength values were: for the geopolymer matrix 3.2 $\mathrm{MPa}$, for $0.5 \%$ fibre addition 4.3 $\mathrm{MPa}$ and for $1 \%$ basalt fibre addition 4.0 MPa. The tensile strength for concrete without fibre was $2.5 \mathrm{MPa}$. The values of bending strength are given in $\mathrm{kN}$. They increased from $16 \mathrm{kN}$ for the geopolymer matrix, through 17.2 $\mathrm{kN}$ for the composite with $0.5 \%$ fibre up to $21 \mathrm{kN}$ for the composite with $1 \%$ fibre. For concrete based on Portland cement, without the addition of fibres, this value was: 9.6 $\mathrm{kN}$ [15].

Research with basalt fibres was also carried out on the basis of a geopolymer matrix composed of metakaolin, slag from the Bolu Cement Company in Turkey, sand and collemanite waste (borate mineral) from the Eti Mining Company mine in Turkey [16]. The tests were carried out with $0.4,0.8$ and $1.2 \%$ fibres addition by volume. The fibre dimension: diameter - $20 \mu \mathrm{m}$ and lengths $-12 \mathrm{~mm}$. The specimens were investigated after 3, 7 and 28 days [16]. The mechanical properties increased in time. The best results for compressive strength were obtained for a sample containing $1.2 \%$ of basalt fibres - 64.8 MPa after 28 days, compared to the sample without reinforcement - $61.6 \mathrm{MPa}$. The best results for bending strength were also obtained for a composite with $1.2 \%$ fibre addition - 12.6 MPa, compared to the plain matrix - 8.8 MPa [16]. The behaviour of geopolymer materials at high temperatures were also be researched, i.e. $300{ }^{\circ} \mathrm{C}$, $600{ }^{\circ} \mathrm{C}$ and $900{ }^{\circ} \mathrm{C}$. Significant deterioration of mechanical properties was found at 
temperatures of $600^{\circ} \mathrm{C}$ and $900^{\circ} \mathrm{C}$, however samples with the addition of fibres still had higher values than the material of the geopolymer matrix [16].

Composites with a basalt fibre content of 0.5 and $1 \%$ by volume were investigated with using geopolymer matrix based on fly ash from the Eraring power plant in the region of New South Wales, Australia. At the same time, the tests were carried out for both - the traditional matrix and the geopolymer foamed with $\mathrm{H}_{2} \mathrm{O}_{2}$ [17]. The fibres had the following dimensions: diameter - $16 \mu \mathrm{m}$ and lengths - $5 \mathrm{~mm}$. Samples were tested after 7 days [17]. In the case of compressive strength for non-foamed geopolymer, no significant differences were found between composites with different basalt fibre content and matrix material. The strength for all samples was about $20 \mathrm{MPa}$. In the case of foamed geopolymer, the addition of fibres resulted in an increasing of compressive strength by about 4.5 MPa [17]. Bending strength tests were carried out for the non-foamed matrix, it showed no significant value changes. It was about $6 \mathrm{MPa}$ for both composites and plain matrix material. It should be noted that the introduction of PVA fibres in the same matrix in analogous amounts increased the flexural strength [17].

Tests with the addition of microfibers were conducted in the scope of compressive strength at ambient temperature $-30{ }^{\circ} \mathrm{C}$, and at elevated temperatures: 200,400 and $800{ }^{\circ} \mathrm{C}[18]$. The tests were carried out on a metakaolin matrix reinforced with basalt microfibers up to $10 \mu \mathrm{m}, 5,10$ and $15 \%$ of microfibers by weight were used [18]. At $30{ }^{\circ} \mathrm{C}$, the composite with $15 \%$ microfibers showed the highest strength properties. Its compressive strength was $38.1 \mathrm{MPa}$, compared to $28.4 \mathrm{MPa}$ for the plain matrix. Tests at elevated temperatures also showed an increasing of compressive strength of all tested samples at $200{ }^{\circ} \mathrm{C}$, and decreasing of strength at higher temperatures. The composite with $15 \%$ addition of microfibers also showed the highest values at $200{ }^{\circ} \mathrm{C}-43.8 \mathrm{MPa}$, compared to the plain matrix - $36.6 \mathrm{MPa}$. At $400{ }^{\circ} \mathrm{C}$ and $800^{\circ} \mathrm{C}$, the highest strength was achieved by a composite with a $10 \%$ of microfiber, it was $23.1 \mathrm{MPa}$ and $16.1 \mathrm{MPa}$, respectively, and for comparison plain matrix had $14.8 \mathrm{MPa}$ and $11.2 \mathrm{MPa}$, respectively [18]

Similar works with the addition of short basalt fibres were carried out on a geopolymer matrix based on fly ash from the Gladstone power plant in Queensland, Australia [19]. The fibres were added in amounts of $0,0.5,1$ and $1.5 \%$ by weight. The tests were carried out at temperatures of $28^{\circ} \mathrm{C}, 200^{\circ} \mathrm{C}, 400^{\circ} \mathrm{C}, 600^{\circ} \mathrm{C}$ and $800^{\circ} \mathrm{C}$. The fibres had dimensions: diameter - $13 \mu \mathrm{m}$ and length - $12.7 \mathrm{~mm}$ [19]. The results of the compressive strength at ambient temperature showed an increasing for samples with short fibres compared to the material without additives. The best results were achieved for $1 \%$ of fibres - ca. $36 \mathrm{MPa}$ (plain matrix: ca. $29 \mathrm{MPa}$ ) [19]. At $200{ }^{\circ} \mathrm{C}, 400{ }^{\circ} \mathrm{C}$ and $600{ }^{\circ} \mathrm{C}$, the 
properties of composites increasing, only at $800{ }^{\circ} \mathrm{C}$ they decreased. The material had the highest strength properties at $400{ }^{\circ} \mathrm{C}$ for composites with 0.5 and $1 \%$ addition of basalt fibre - ca. $45 \mathrm{MPa}$, while for 1.5\% and the control sample was over $35 \mathrm{MPa}$ [19]. Studies confirmed the resistance of basalt fibre geopolymers to elevated temperatures $[18,19]$.

It is also worth paying attention to the research on the addition of basalt fibres to fly ash (class C) from the power plant in Thailand. In these studies, a very high weight proportion of basalt fibres was used: 0, 10, 15, 20, 25 and 30\% [20]. The compressive strength tests were carried out after 7 and 28 days. All composites with the addition of basalt fibres obtained higher compressive strength than the basic matrix. The optimal addition was $10-15 \%$ of fibres [20]. At the same time, the composite with $15 \%$ fibres content achieved its maximum compressive strength - $44 \mathrm{MPa}$ after 7 days and the same value was maintained after 28 days. The composite with 10\% fibre content reached almost $40 \mathrm{MPa}$ after 7 days, however, this value increased and after 28 days was about $45 \mathrm{MPa}$. For comparison, the results for the composite without fibre after 7 and 28 days were ca. $37 \mathrm{MPa}[20]$.

As regards other mineral additives, work was carried out on fibres based on silica, aluminium oxide and zirconium [21]. Other mineral additives used in geopolymer composites include diatomaceous earth [22], however, this additive was not introduced in the form of fibres, but grains with a diameter of $1.2 \mu \mathrm{m}$ and wollastonite, also introduced in the form of micro-additives $[23,24]$.

\section{Materials and Methods}

\subsection{Materials}

The matrix was made with using fly ash without any aggregate. The fly ash was delivered from the bituminous coal power plant 'Skawina' (located in: Skawina, Lesser Poland, Poland). It is obtained as combustion by-product through the electrostatic precipitation of fine particles from the exhaust gases from coal-fired furnaces.

The chemical composition of this fly ash is typically for class $F$ [25]. It contains less than $5 \%$ of unburned material, less than $10 \%$ of iron compounds and low amount calcium compounds. The amount of the reactive silica in investigated material is reasonable ca. 36\%. It has good physical parameters - the content of particle under the size 45 $\mu \mathrm{m}$ is ca. $88 \%[25,26]$. The fly ash contains a lot of spherical particles and has good workability [26]. The mineralogical structure investigations show the large amount of 
amorphous phase [26]. The fly ash has a features that predestine it as a raw material in geopolymerization process.

As the reinforcement the short basalt fibres has been applied (Figure 1).

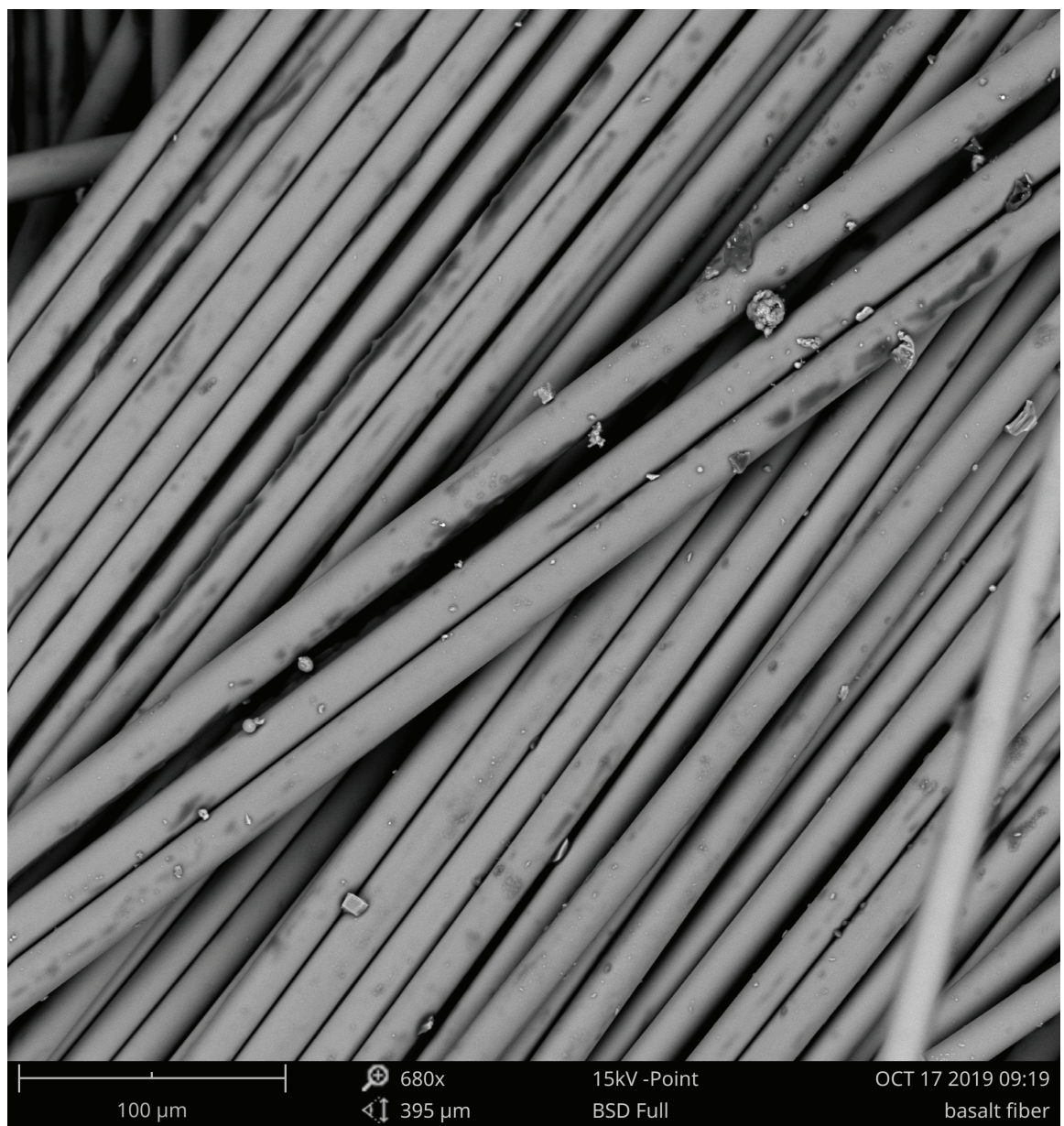

Figure 1: SEM image - basalt fibres.

The fibres were about $5 \mathrm{~mm}$ length. They have been added in amount 1 and $2 \%$ by weight.

\subsection{Samples preparation}

Samples were prepared using sodium promoter, fly ash and basalt fibres. The synthesis of geopolymers was made with using $8 \mathrm{M}$ ratio sodium hydroxide solution. The three kind of samples were prepared:

1. plain samples (geopolymer mortar without fibres addition),

2. with addition of $1 \%$ short basalt fibres by weight,

3. with addition of $2 \%$ short basalt fibres by weight. 
The fly ash, alkaline solution and fibres were mixed manually about 5 - 10 minutes to receive the homogeneous paste. Next, it was poured into sets of plastic moulds. The samples were hand-formed. There were left in laboratory condition for curing for $24 \mathrm{~h}$. Next, there were heated in the laboratory drying cabinet for $8 \mathrm{~h}$ at $75^{\circ} \mathrm{C}$ and left in the drying cabinet till they reach ambient temperature. Then, the samples were unmoulded. They were investigated after 7,14 and 28 days.

\subsection{Analytical procedure}

The morphology was investigated by scanning electron microscope (SEM) on Phenom ProX. The research has been made for fibres and the samples previously broken during compressive strength tests. The investigations were made at various magnifications.

Compressive strength tests were performed according to the methodology described in the standard EN 12390-3. ('Testing hardened concrete. Compressive strength of test specimens'), because of the lack of separate standards for geopolymer materials. The tests involved at least 15 samples. Tests were provided on universal testing machine: Anyagvizsgáló Készülékek Gyára Budapest, type: SZF-1 with additional devices for measurement: Hottinger Baldwin Messtechnik GmBh. Samples used to the compressive strength test had cubic shape and dimensions (approx.): $20 \mathrm{~mm} \times 20 \mathrm{~mm} \times 20 \mathrm{~mm}$.

\section{Results and Discussion}

\subsection{Microstructure investigations}

The SEM observations were made for fibres (Figure 1) as well as for composition reinforced by fibres (Figures 2, 3 and 4). The images were made at various magnifications.

The observation of microstructure of composites gave a preliminary information about the distribution of fibres (Figure 2) and coherency of fibres and the geopolymer matrix (Figures 3 and 4).

The fibres are evenly distributed in all volume of the material (Figure 2). It is clearly visible that they are oriented in different directions. The material is probably anisotropic and the fibre distribution was regular. The fibre distribution in the matrix influences the properties of the specific composite. In case of the fibres aggregation appearance it could decrease its mechanical properties.

The microstructural observation also allows to notice that the structure is coherent and the fibres have good connection with matrix (Figure 3). Moreover, the some fibres 


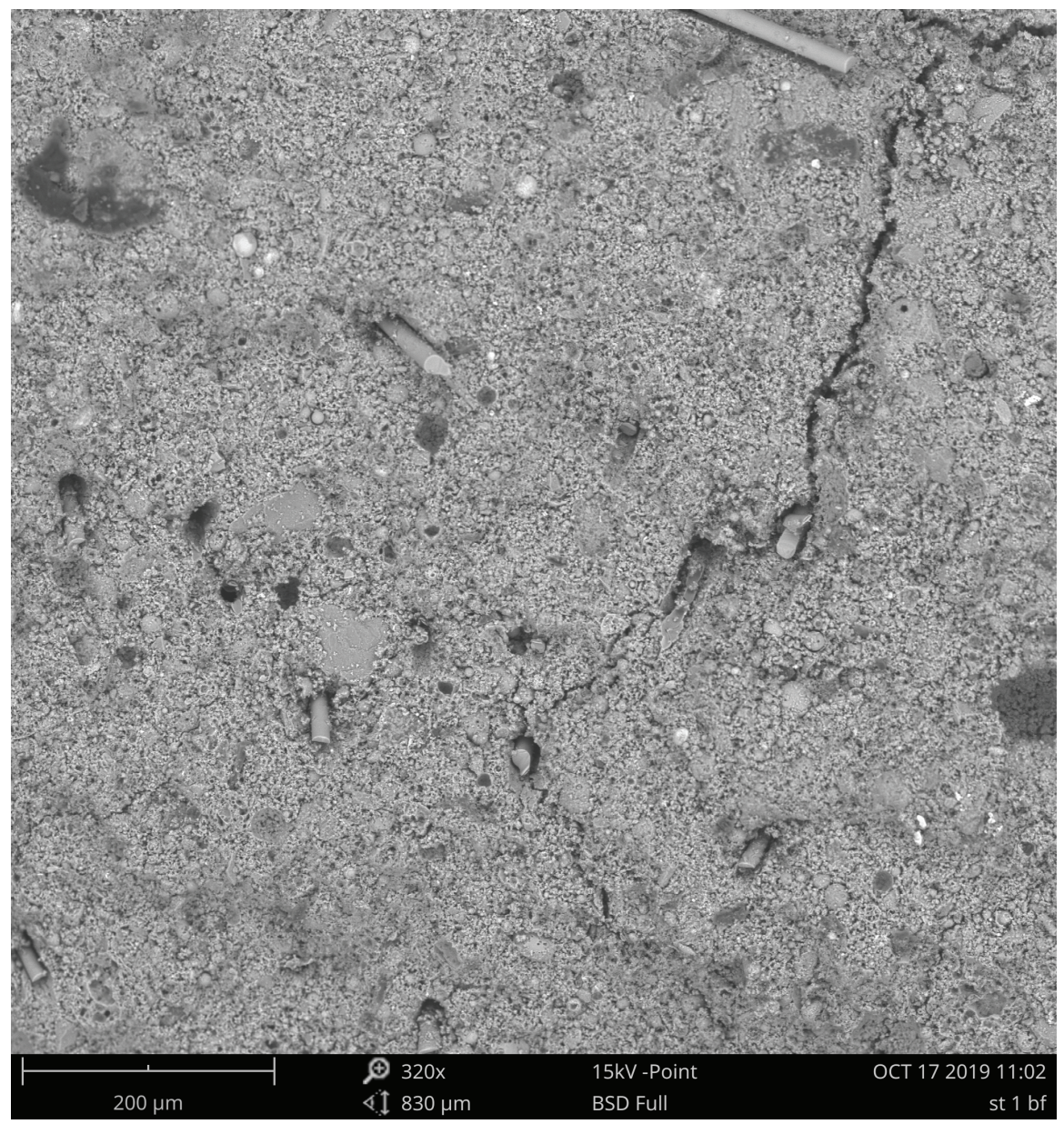

Figure 2: SEM image: composite with basalt fibres - distribution of fibres in composite.

probably have been partly dissolved (in the right upper corner in the Figure 3 we see shell after the basalt fibre).

In the Figure 3 and 4 there is also visible the suppression the cracking by the fibre. The cracking is limited by the fibre presence (Figure 4). Additionally the fibre in the Figure 3 probably has been broken by the force during the compressive strength test. It shows that the fibres are actively involved in strength transmission.

The SEM observations allow to orient in overall structure of the composite and the role of fibres. The high coherence with matrix were noticed.

\subsection{Mechanical properties - compressive strength}

The results of the compressive strength tests are shown in Table 1.

The best results have been achieved for plain matrix after 28 days. It was more than $13 \mathrm{MPa}$. The achieved results are not coherent with predictions and literature sources 


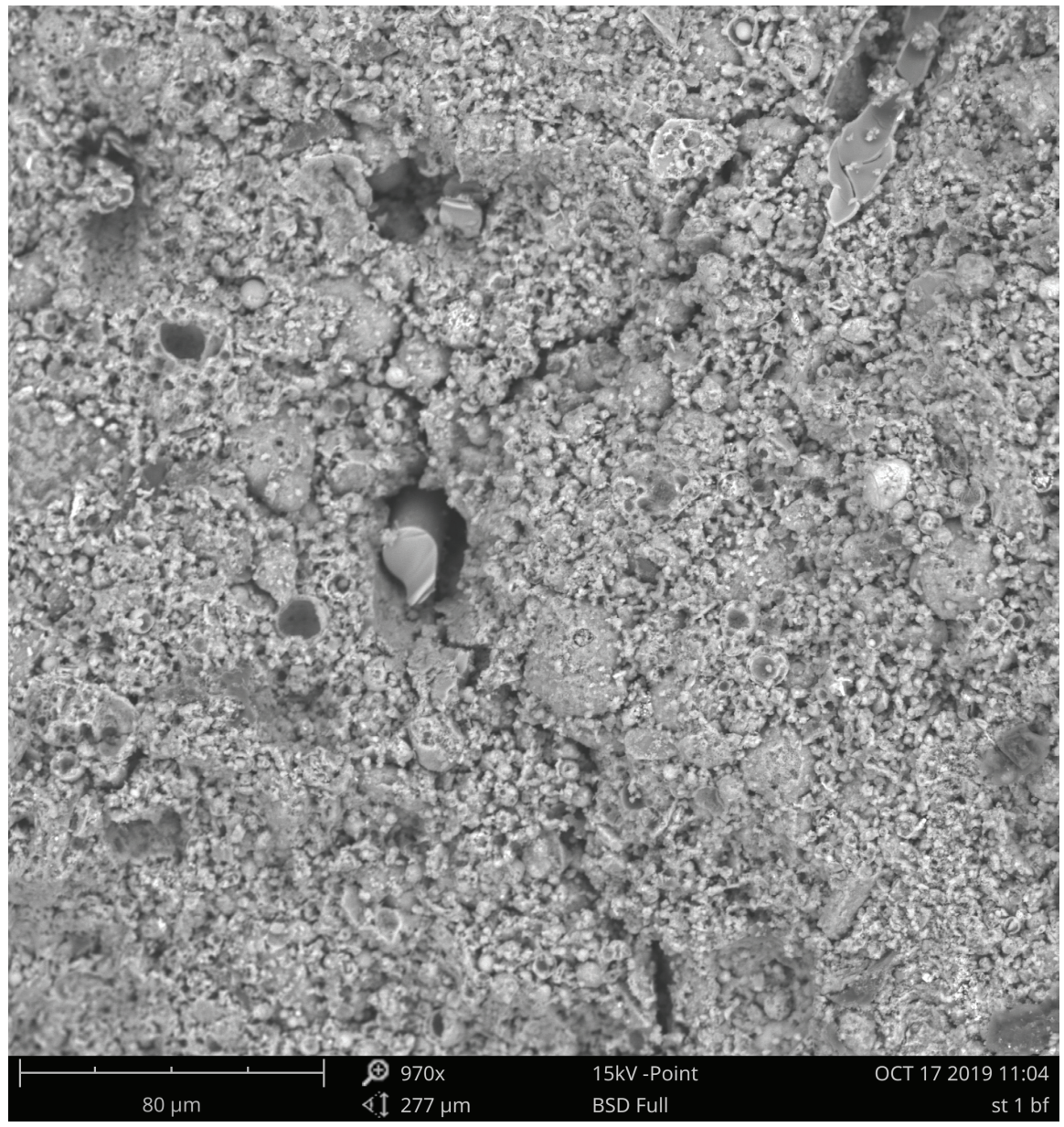

Figure 3: SEM image: composite with basalt fibres - basalt fibres and the cracking propagation.

TABLE 1: The results of compressive strength

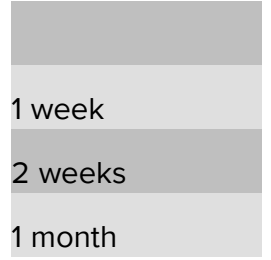

Basic sample
9.8 MPa (s.d.: 0.8)
10.0 MPa (s.d.: 2.7 )
13.1 MPa (s.d.: 1.7)

1\% basalt fibres
8.7 MPa (s.d.: 1.0)
$7.9 \mathrm{MPa}$ (s.d.: 0.8)
$10.7 \mathrm{MPa}$ (s.d.: 1.1)

$2 \%$ basalt fibres

12.8 MPa (s.d.: 1.0)

8.7 MPa (s.d.: 0.7)

11.9 MPa (s.d.: 0.8)

s.d. = standard deviation

that show that compressive strength should increase according to the curing time [1116]. This trend was only visible for the plain samples. For the samples with fibres this trend was not coherent. The achieved results show that the compressive strength for the samples with fibres was lower after two weeks in comparison with the samples after 1 week.

The compressive strength changes also depend on the fibre content. It is usually lower than for plain samples, the exception are the samples after 1 week with $2 \%$ of basalt fibres. The lower values for compressive strength for the samples with fibres have 


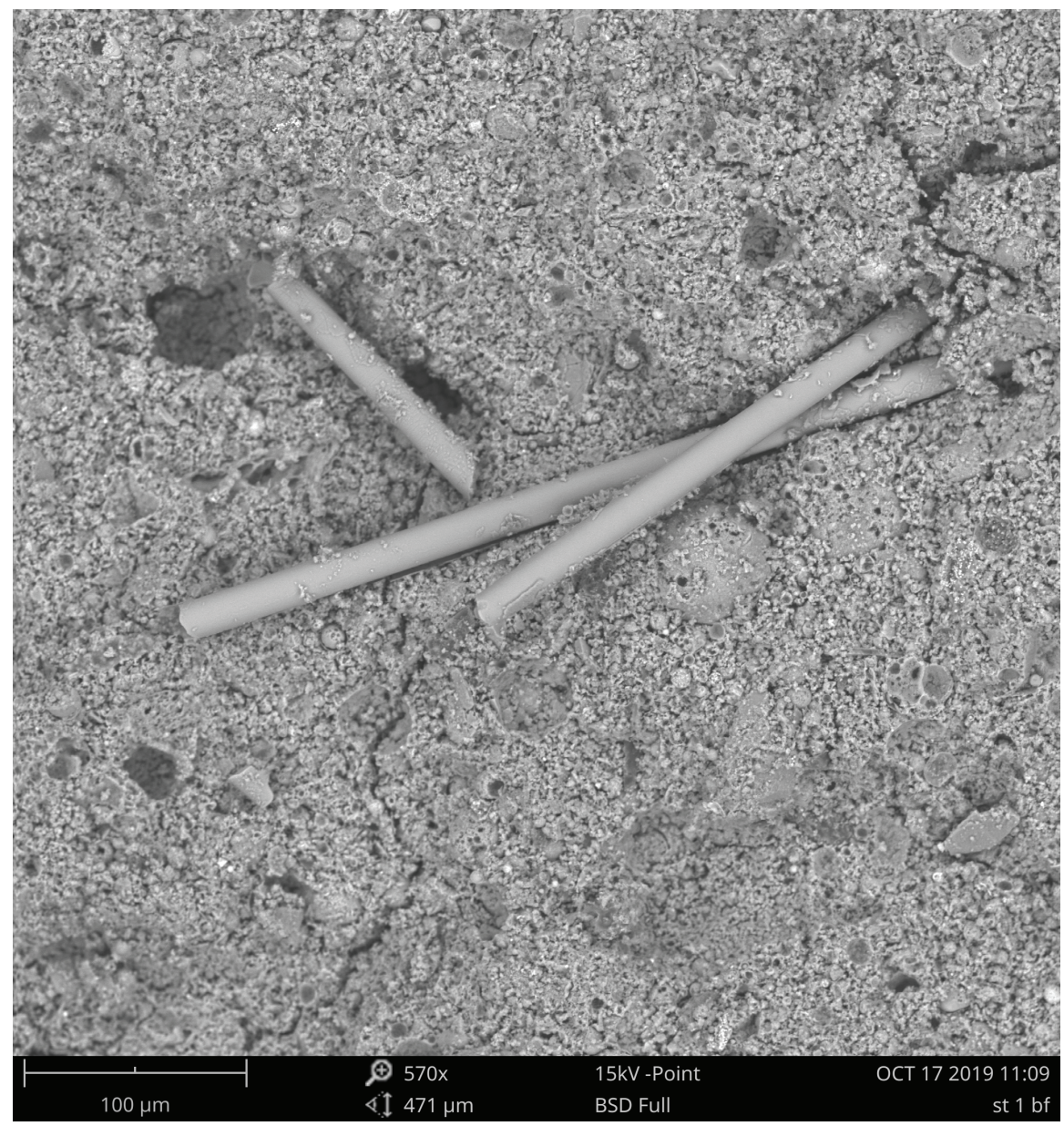

Figure 4: SEM image: composite with basalt fibres - basalt fibres.

been previously reported in the literature [15]. However most of provided researches show rather increasing for this value $[13,16,18]$ or lack of significant difference [17].

Next, the results of the compressive strength test have been compared with the samples' density (Table 2).

TABLE 2: Density of the samples

1 week
2 weeks
1 month

\begin{tabular}{|} 
Plain sample \\
$\begin{array}{c}1.49 \mathrm{~g} / \mathrm{cm}^{3} \\
1.60 \mathrm{~g} / \mathrm{cm}^{3} \\
1.47 \mathrm{~g} / \mathrm{cm}^{3}\end{array}$
\end{tabular}

\begin{tabular}{|c|}
$1 \%$ basalt fibres \\
$1.48 \mathrm{~g} / \mathrm{cm}^{3}$ \\
$1.46 \mathrm{~g} / \mathrm{cm}^{3}$ \\
$1.44 \mathrm{~g} / \mathrm{cm}^{3}$
\end{tabular}

$2 \%$ basalt fibres
$1.52 \mathrm{~g} / \mathrm{cm}^{3}$
$1.47 \mathrm{~g} / \mathrm{cm}^{3}$
$1.43 \mathrm{~g} / \mathrm{cm}^{3}$

Changes of density should be correlated with compressive strength. For the investigated samples this tendency did not appear. The lowest density is for samples with $2 \%$ of basalt fibres after 1 month and the compressive strength for this samples is $11.9 \mathrm{MPa}$. The highest density is for the plain samples after 2 weeks, but the compressive strength for this samples is lower - only 10.0 MPa. However differences in the density were not 
significant. There is no correlation between the density and compressive strength for this series of samples.

The research also allows to observe indirectly the change in the samples behaviour. The plain samples were broken in brittle way (Figure 5), whereas for the samples with fibre the mechanism of crashing was more ductile (Figure 6).

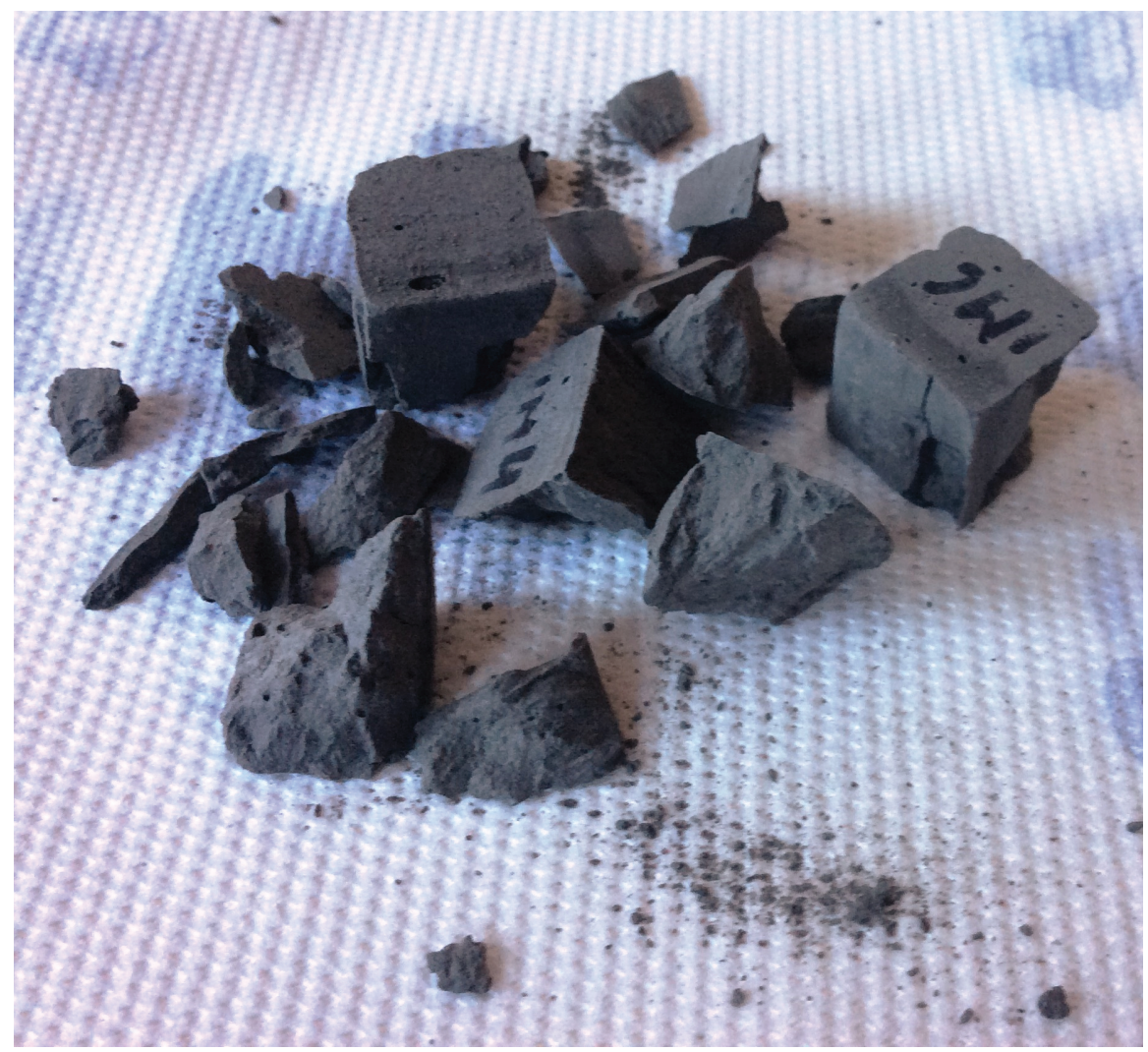

Figure 5: Samples without fibres after compressive strength test.

The changing of the behaviour is coherent with the research reported in the literature.

It is worth to notice that the research were conducted for the geopolymer mortar without any aggregate, because of that the achieved values for compressive strength are relatively low in comparison with other reported in literature [11-19]. The sand addition could significantly improve this value.

\section{Conclusions}

Geopolymer composites based on fly ash reinforced with different amounts of basalt fibres have been manufactured and characterized. The composites were prepared using sodium promoter. The microstructure observation showed regular distribution and coherence fibres with the matrix. The results for this investigations are according to 


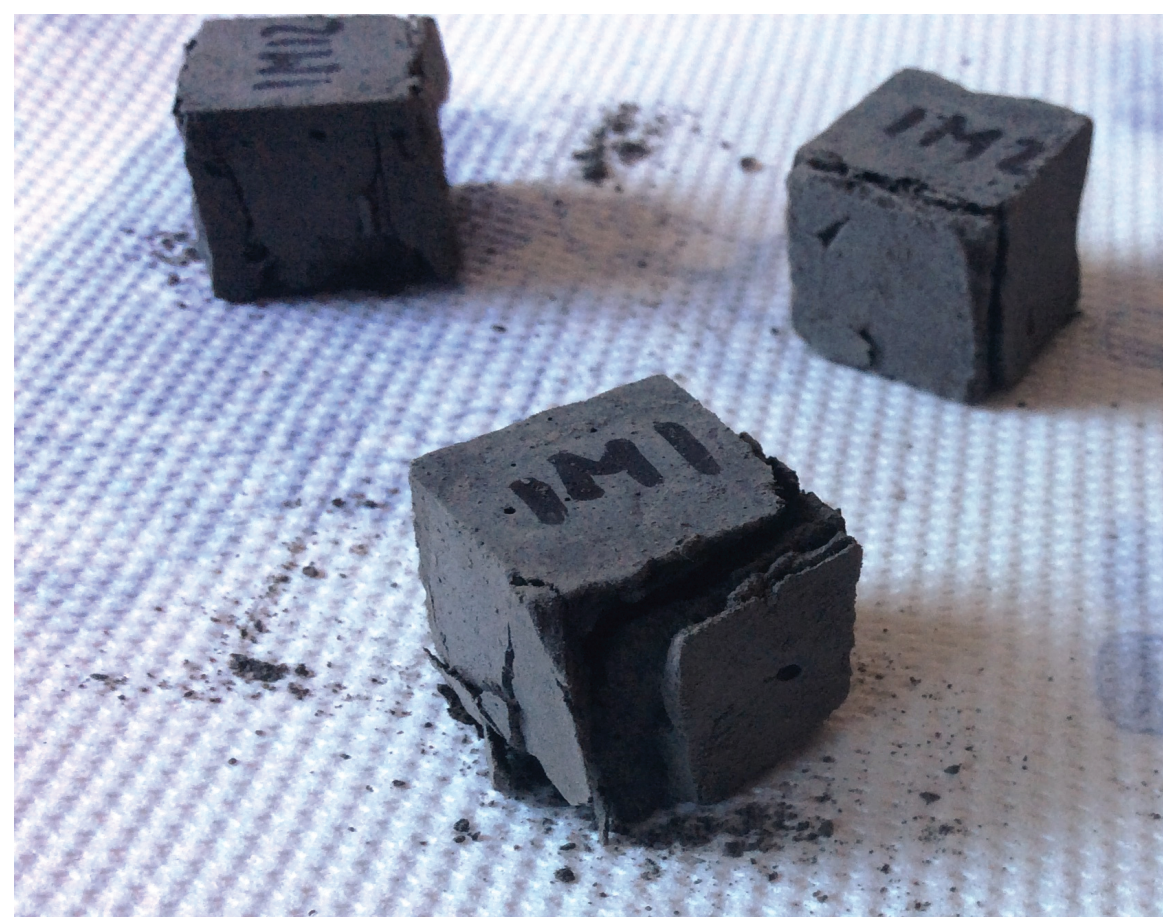

Figure 6: Samples with $2 \%$ of basalt fibres after compressive strength test.

the prediction and literature sources. The results for compressive strength are slightly different than predicted and only partly coherent with other researches that have been published. The addition of $1 \%$ of basalt fibres decreased the compressive strength. The results for $2 \%$ of fibres addition are inconclusive. Firstly the compressive strength increased (after 7 days period), but next (after 14 and 28 days) it is lower than for basic matrix.

The fibre addition did not improve the compressive strength (after 28 days) of the composite significantly, but the presence of the fibres changes the character of failure mechanism from brittle to ductile. The changing the behaviour during the cracking form brittle to more ductile increases the safety of the material in potential application in construction industry. This study also presents that it is possible to produce the composites of reasonable properties from the fly ash and basalt fibres. This kind of composites could be applied in construction industry for the bricks, pavement elements and others.

\section{Founding}

1. The research was made partly by the support of Tempus Public Foundation in the framework Bilateral State Scholarships. 2. This work has been financed by the by Polish National Agency for Academic Exchange under the academic exchange programme as 
part of bilateral cooperation with Czech Republic and Hungary. 3. This work has been supported by the ERANet-LAC 2nd Joint Call (http://www.eranet-lac.eu) funded by the National Centre for Research and Development in Poland, within the framework of the grant: Development of eco-friendly composite materials based on geopolymer matrix and reinforced with waste fibers. 4. The described work was carried out as part of the Innovative fine grinding - particle design technologies laboratory development at the University of Miskolc in the Centre of Excellence on Sustainable Natural Resources Management, GINOP-2.3.3-15-2016-00019 project in the framework of the Széchenyi 2020 Program. The realization of this project is supported by the European Union, co-financed by the European Social Fund.

\section{References}

[1] Soltan, D.G. and Li V.C. (2018). A self-reinforced cementitious composite for buildingscale 3D printing. Cement and Concrete Composites, vol. 90, pp. 1-13.

[2] Szechyńska-Hebda, M., et al. (2019). Optimal Design of pH-neutral Geopolymer Foams for Their Use in Ecological Plant Cultivation Systems. Materials, vol. 12, 2999.

[3] Zhu, B., et al. (2019). Development of 3D printable engineered cementitious composites with ultra-high tensile ductility for digital construction. Materials and Design, vol. 181, 108088.

[4] Silva, G., et al. (2018). A Comparative Study of Linen (Flax) Fibers as Reinforcement of Fly Ash and Clay Brick Powder Based Geopolymers. IOP Conf. Series: Materials Science and Engineering, vol. 416.

[5] Furtos, G., et al. (2019). Mechanical properties of wood fiber reinforced geopolymer composites with sand addition. Journal of Natural Fibers, vol. 1, pp. 1-12.

[6] Thang, X.N., Louda, P. and Kroisova, D. (2013). Thermophysical properties of woven fabrics reinforced geopolymer composites. World Journal of Engineerin", vol. 10, no. 2, pp. 139-144.

[7] Samal, S., Thanh, N.P., Petrikova, I. and Marvalova, B. (2015). Improved Mechanical Properties of Various Fabric-Reinforced Geocomposite at Elevated Temperature. The Journal of The Minerals, Metals and Materials Society, vol. 67, issue 7, pp. 1478-1485.

[8] Skupień, P., Hilbig, A. and Muller, E. (2005). Wytwarzanie i właściwości kompozytów na osnowie geopolimerowej zbrojonych włóknem bazaltowym. Inżynieria materiałowa, vol. 3, pp. 139-143.

[9] Welter, M., Schmücker, M. and MacKenzie K.J.D. (2015). Evolution of the FibreMatrix Interactions in Basalt-Fibre-Reinforced Geopolymer-Matrix Composites after 
Heating. Journal of Ceramic Science and Technology, vol. 6, issue 1, pp. 17-24.

[10] Jasiczek, M., et al. (2010). Nowoczesne kompozyty nieorganiczne na osnowie geopolimerów wzmocnionych włóknami szklanymi, węglowymi oraz bazaltowymi. Inżynieria Materiałowa, no. 4/2010, pp. 993-996.

[11] Ren, D., et al. (2017). Durability performances of wollastonite, tremolite and basalt fiberreinforced metakaolin geopolymer composites under sulfate and chloride attack. Construction and Building Materials, vol. 134, pp. 56-66.

[12] Rill, E., Lowry, D. R. and Kriven W. M. (2010). Properties of basalt fiber reinforced geopolymer composites in Strategic Materials and Computational Design - A Collection of Papers Presented at the 34th International Conference on Advanced Ceramics and Composites, 10th ed., vol. 31, pp. 57-67.

[13] Ronad, A., Karikatti, V.B. and Dyavanal S.S. (2016). A Study on Mechanical Properties of Geopolymer Concrete Reinforced with Basalt Fiber. IJRET: International Journal of Research in Engineering and Technology, vol. 5, issue 7, pp. 474-478.

[14] Guo, X. and Pant, X. (2018). Mechanical properties and mechanisms of fiber reinforced fly ash-steel slag based geopolymer mortar. Construction and Building Materials, vol. 179, pp. 633-641.

[15] Dias, D.P. and Thaumaturgo, C. (2005). Fracture toughness of geopolymeric concretes reinforced with basalt fibers. Cement and Concrete Composites, vol. 27, pp. 49-54.

[16] Celik, A., et al. (2018) High-temperature behavior and mechanical characteristics of boron waste additive metakaolin based geopolymer composites reinforced with synthetic fibers. Construction and Building Materials, vol. 187, pp. 1190-1203.

[17] Masi, G., Rickard, W.D.A., Bignozzi, M.C. and van Riessen A. (2015). The effect of organic and inorganic fibres on the mechanical and thermal properties of aluminate activated geopolymers. Composites: Part B, vol. 76, pp. 218-228.

[18] Behera, P., Baheti, V., Militky, J. and Louda, P. (2018). Elevated temperature properties of basalt microfibril filled geopolymer composites. Construction and Building Materials, vol. 163, pp. 850-860.

[19] Shaikh, F. and Haque, S. (2018) Behaviour of Carbon and Basalt Fibres Reinforced Fly Ash Geopolymer at Elevated Temperatures,. International Journal of Concrete Structures and Materials, vol. 12, issue 35, pp. 1-12.

[20] Timakul, P., Rattanaprasit, W. and Aungkavattana, P. (2016). Improving compressive strength of fly ash-based geopolymer composites by basalt fibers addition, Ceramics International, vol. 42, pp. 6288 - 6295. 
[21] Bagci, C., Kutyla, G.P. and Kriven W.M. (2017). Fully reacted high strength geopolymer made with diatomite as a fumed silica alternative. Ceramics International, vol. 43, pp. 14784-14790.

[22] Vickers, L., van Riessen, A. and Rickard, W.D.A. (2015). Fire-Resistant Geopolymers. Role of Fibres and Fillers to Enhance Thermal Properties. (London : Springer).

[23] Silva, F.J. and Thaumaturgo, C. (2003). Fibre reinforcement and fracture response in geopolymeric mortars. Fatigue and Fracture of Engineering Materials and Structures, vol. 26, issue 2, pp. 167-172.

[24] Yan, S. and Sagoe-Crentsil, K. (2012). Properties of wastepaper sludge in geopolymer mortars for masonry applications. Journal of Environmental Management, vol. 112, pp. 27-32.

[25] Korniejenko, K., Halyag, N.P. and Mucsi, G. (2019). Fly ash as a raw material for geopolymerisation - chemical composition and physical properties. IOP Conf. Series: Materials Science and Engineering, vol. 706, 012012.

[26] Korniejenko, K., et al. (2019). Fly ash as a raw material for geopolymerisationmineralogical composition and morphology. IOP Conf. Series: Materials Science and Engineering, vol. 706, 012006. 